\title{
Ação coletiva e movimentos sociais: em busca de uma metodologia analítica'
}

Josimar Priori Celene Tonella $a^{3}$

\section{Resumo}

Busca-se neste artigo apresentar os resultados de uma pesquisa realizada com associações de moradores no município de Sarandi - Paraná. A incorporação de um conjunto de referências teóricas que valorizam a ação humana sem negligenciar a influência da estrutura permitiu fazer uma análise da ação política de sujeitos associativos, reconhecendo sua capacidade criativa, mas considerando ao mesmo tempo as influências histórico-sociais, seja no nível local ou no mais amplo. Tal pesquisa nos levou a identificar a constituição de três padrões de atuação no conjunto das associações de moradores em Sarandi, quais sejam, democrático-participativo, governista e o que chamamos de seleção estratégica, termo cunhado por nós a partir da análise dos dados da pesquisa.

Palavras-chave: Ação humana. Projeto político. Democracia.

\section{Introdução}

O objetivo deste artigo é apresentar uma metodologia teórico-analítica sobre organizaçóes populares a partir de um estudo realizado no município de Sarandi-PR com associaçóes de moradores. A pesquisa foi norteada pelo esforço de realizar uma abordagem que pudesse revelar o perfil dos diferentes sujeitos associativos, bem como as referências que buscam para fundamentar sua ação, sem, no entanto, rotulá-los a priori como sujeitos democráticos ou autoritários. Para tanto, o entendimento é que as características desses sujeitos só podem ser determinadas a posteriori, ou seja, após a investigaçáo.

\footnotetext{
1 Uma versão preliminar deste artigo foi apresentada no III Fórum de Ciência Política, ocorrido na Universidade Federal do Paraná (UFPR), entre os dias 31 de julho e 2 de agosto de 2013.

2 Professor do Instituto Federal do Paraná (IFPR). Pesquisador do NaMargem - Núcleo de Pesquisas urbanas Centro de Estudos da Metrópole (CEM). Email: josimarpriori@hotmail.com.

3 Professora Associada do Departamento de Ciências Sociais e do Programa de Pós-Graduação em Ciências Sociais da Universidade Estadual de Maringá (PCC/UEM). Email: ctonella@uol.com.br.
} 
A fundamentação teórica foi buscada num conjunto de autores que vai desde Karl Marx, Edward Thompson, Hannah Arendt e passa por Eder Sader, Marcelo K. Silva, Goetz Ottmann e Evelina Dagnino. Concebemos, entáo, a dialética que existe entre sujeito e estrutura, o que permite a manifestaçáo da ação humana, condiçáo distintiva da política, segundo Hannah Arendt. O conceito de projeto político de Evelina Dagnino é central na análise, pois permite conceber a política como disputa, não apenas no nível institucional, mas em toda extensão da sociedade. Sáo referências que os diferentes sujeitos acessam, produzem e reproduzem e que orientam sua açáo política.

Empiricamente, encontramos no município de Sarandi um conjunto associativo marcado por diferentes vertentes de atuaçáo, náo raro antagônicas entre si, mas também sujeitos que incorporam elementos de diferentes projetos políticos e os mobilizam como estratégias políticas para obtençấo de suas demandas. A principal estratégia de pesquisa foi a realizaçáo de entrevistas semiestruturadas com os presidentes das respectivas associaçóes de moradores deste município, as quais analisaremos neste artigo ${ }^{4}$.

Os principais resultados indicam, antes de tudo, uma pluralidade existente no interior destas associaçóes, as quais estáo filiadas a diferentes projetos políticos. De partida, identificou-se um conjunto de associaçóes ligadas ao que podemos chamar de tradiçâo dos movimentos sociais brasileiros. Tais associaçóes são herdeiras de um projeto político democrático-participativo formulado no Brasil a partir dos anos 1980, mas que chega a Sarandi somente no final dos anos 1990, por meio da atuação de lideranças religiosas ligadas à teologia da libertaçáo e de militantes de esquerda ligados ao marxismo e ao Partido dos Trabalhadores.

Por outro lado, sobretudo nos últimos anos, fortaleceu-se em Sarandi uma vertente associativa marcada pela preocupaçáo com a parceria com o governo municipal. Tais associaçóes rechaçam as açóes conflitivas de outras

4 Entre janeiro e março de 2012 foram entrevistados 26 presidentes ou, na ausência destes, lideranças de associações de moradores do municipio de Sarandi. Entre os entrevistados, consta o presidente da União Sarandiense de Associações de Moradores (UNISAM). Complementarmente, a observação de atividades realizadas pelas associações e a pesquisa documental foram estratégias mobilizadas para mapear o terreno pesquisado. conhecer as principais lideranças, estabelecer interlocução com os sujeitos desta pesquisa, bem como preencher lacunas não respondidas ao longo das entrevistas. Em Priori (2013) exploramos mais detidamente nossas escolhas metodológicas. 
associaçóes e movimentos sociais de Sarandi e reconhecem na aliança com o prefeito municipal o melhor caminho para obtenção das demandas dos seus bairros. É notável, assim, que até mesmo como as demandas são concebidas diverge entre os dois grupos.

Em meio a estas duas vertentes, emerge nesse contexto uma terceira configuração associativa, nominada neste artigo de seleção estratégica devido à mobilização de estratégias de diferentes projetos políticos. Assim, embora neste grupo haja os que prefiram uma ação mais combativa ou mais conciliadora, não hesitam em recorrer a formas de luta mais próximas de outro projeto político.

A seleção estratégica é entendida como a capacidade das lideranças em compreenderem os diferentes projetos políticos em disputa, os formatos correspondentes de atuaçáo e em elegerem aqueles que entendem mais eficazes e potentes para influenciar os órgãos públicos e garantir conquistas objetivas para as respectivas associaçóes. Em outras palavras, o sujeito associativo tem a sua disposição quadros de referências distintos, crenças e visóes de mundo, representaçóes e ferramentas de açáo políticas diferentes e umas e outras sáo medidas pela sua funcionalidade na conquista de suas necessidades associativas. Assim, as diferentes referências são acessadas como se fizessem parte de um estoque amplo e composto de diversas modalidades de estratégias. Da mesma forma, diferentes mediadores políticos sáo mobilizados conforme a conveniência.

Assim, as referências teóricas utilizadas nesta pesquisa nos permitiram buscar as configuraçóes de associaçóes de moradores e reconhecer as contradiçôes internas a estas associaçóes, bem como compreender os trânsitos que pelo menos algumas associaçóes realizam entre distintas concepçóes políticas.

\section{Em busca de uma metodologia analítica}

A pesquisa realizada com organizaçóes sociais no município de Sarandi, no interior do Paraná, foi norteada pelo esforço de compreender a complexidade do fenômeno estudado e, portanto, fugir das simplificaçóes. Para tanto, por um lado, buscamos tomar contato com a realidade estudada e com os sujeitos da pesquisa, tentando, o tanto quando possível, ouvi-los e entender a forma como eles se identificam. Por outro ladro lado, nos apoiamos num conjunto de referências teóricas que nos permitiram a compreensáo da complexidade dos significados da açáo destes sujeitos. Inserida dentro da temática 
dos movimentos sociais, o objetivo da pesquisa foi compreender as configuraçôes sociais assumidas por associaçôes de moradores no município de Sarandi.

Uma das preocupaçóes centrais da pesquisa foi romper com as determinaçóes econômicas ou culturais e com as dicotomias, tais como indivíduo $\mathrm{X}$ sociedade, sujeito X objeto e Estado X sociedade civil. A compreensáo é que estes elementos são momentos de um todo complexo formado ao mesmo tempo por indivíduos e sociedade, Estado e sociedade civil, estrutura econômica e cultural. Com efeito, nenhum desses elementos existe independentemente dos outros e só se realizam inseridos em um contexto social.

Esta reflexão parte de Karl Marx, autor que evidenciou, ao menos nas obras históricas, a influência da sociedade sobre o indivíduo, sem se furtar, no entanto, de reconhecer as possibilidades de açáo do sujeito, ainda que sob condiçóes historicamente determinadas 5 . De fato, Marx afirma que

Os homens fazem a sua própria história, mas não a fazem como querem; não a fazem sob circunstâncias de sua escolha e sim sob aquelas com que se defrontam diretamente, legadas e transmitidas pelo passado. A tradição de todas as gerações mortas oprime como um pesadelo o cérebro dos vivos (MARX, 1997, p. 21).

$\mathrm{Na}$ obra em que a citaçáo acima se encontra, a saber, $O 18$ brumário de Luís Bonaparte, Marx analisa a açâo das diversas classes sociais na sua singularidade construída nas disputas reais. Assim, elas não são predeterminadas material ou teoricamente e simplesmente reproduzem o que as condiçóes estruturais determinam. Elas agem, acertam, erram, interagem e se reconstituem. Enfim, sáo os homens que fazem sua história, ainda que herdem das geraçóes passadas o cenário no qual atuaráo. São eles os sujeitos da história e eles que definem, pelos menos parcialmente, seus destinos.

Esta famosa passagem de Marx pode nos remeter à relação entre o indivíduo e a sociedade - assim como à relaçáo entre sujeito e objeto - e nos levar a perguntar até que ponto as condiçóes materiais definem a ação do indivíduo.

5 A relação entre estrutura e superestrutura é, sem dúvida, um dos capítulos mais discutidos na história do marxismo. Tal controvérsia não será levada adiante neste artigo, mesmo porque já foi debatida exaustivamente. Assim, reservo-me a interpretação apresentada nestas páginas, a qual está baseada nas considerações de Marx encontradas em 018 brumário (1997) e nas considerações de Thompson (2011; 2012) e Williams (1979). 
Em outras palavras, somos impulsionados a pensar no grau de determinação daquilo que a literatura marxista clássica costumou chamar de condiçôes objetivadas dadas.

Edward P. Thompson soube lidar com este problema sem, contudo, negligenciar a liberdade e a açáo humana. O clássico de Thompson, A formação da classe operária inglesa, é uma obra exemplar para a reflexão em questão. $\mathrm{O}$ argumento que perpassa a obra é que a classe operária inglesa tanto foi formada como se fez a si mesma. Assim, afirma o historiador inglês: "a classe operária não surgiu tal como o sol, numa hora determinada. Ela estava presente no seu próprio fazer-se" (THOMPSON, 2011, p. 9).

Esta vertente de interpretação da obra de Karl Marx procura escapar dos reducionismos economicistas e reconhecer a açáo humana como elemento construtor da história. Para Thompson, existe um grande espaço entre a determinação e a forma como os homens em seus contextos históricos específicos elaboram sua experiência: "a consciência de classe surge da mesma forma em tempos e lugares diferentes, mas nunca exatamente da mesma forma ${ }^{6 "}$ (THOMPSON, 2011, p. 10).

Este autor se propóe a realizar um trabalho que busca interpretar a história passada não por meio das preocupaçóes futuras ${ }^{7}$, mas por si mesma. Isto é, Thompson objetiva recuperar a experiência do período estudado, sem buscar explicar evoluçóes posteriores com bases no passado. Neste sentido, o autor realiza uma historiografia, por assim dizer, dos silenciados. Crítico de uma vertente em que "os becos sem saída, as causas perdidas e os próprios perdedores sấo esquecidos" (THOMPSON, 2011, p. 14), o autor pretende compreender os sujeitos estudados por sua própria experiência ${ }^{8}$.

6 A afirmação de Thompson de que "causas que foram perdidas na Inglaterra poderiam ser ganhas na Ásia ou na África" (2011, p. 15) explicita bem o caráter de "fabricação" da consciência.

7 Para Thomson, "não deveriamos ter como único critério de julgamento o fato de as ações de um homem se justificarem, ou não, à luz da evolução posterior" (THOMPSON, 20II, p. 14).

8 "Estou tentando resgatar o pobre tecelão de malhas, o meeiro luddita, o tecelão do 'obsoleto' tear manual, o artesão 'utópico' e mesmo o iludido seguidor de Joanna Southcott, dos imensos ares superiores de condescendência da posteridade. Seus ofícios e tradições podiam estar desaparecendo. Sua hostilidade diante do novo industrialismo podia ser retrógada. Seus ideais comunitários podiam ser fantasiosos. Suas conspirações insurrecionais podiam ser temerárias. Mas eles viveram nesses tempos de aguda perturbação social, $e$ nós não. Suas aspirações eram válidas nos termos de sua própria experiência; se foram vítimas acidentais da história, continuam a ser, condenados em vida, vitimas acidentais" (THOMPSON, 2011, p. 14). 
Mesmo correndo o risco de fazer uma transiçáo muito rápida, considerando o limite deste artigo, reporto-me a Eder Sader (1988), autor de um estudo clássico sobre as novas configuraçóes da classe trabalhadora brasileira, mais precisamente da região da Grande Sáo Paulo, nos anos 1970 e 1980. De acordo com Sader (1988), a partir do que foi chamado "condiçóes objetivas dadas", não é possível deduzir as especificidades do comportamento dos sujeitos sociais.

Claramente influenciado, entre outros, por Thompson', Sader (1988) chama a atenção para as experiências e ressignificaçóes que os sujeitos operaram atribuindo novos sentidos e valores às suas necessidades de reprodução. Para o autor, restringir a explicaçáo à análise de condiçóes estruturais, oculta o que "[...] os antropólogos chamaram de 'enorme plasticidade do organismo humano': ou seja, a grande gama de respostas possíveis diante de uma mesma solicitaçáo dada" (SADER, 1988, p. 41). Sader (1988) salienta que limitar a explicação a "condiçóes objetivas" acaba por deixar de considerar a autonomia dos sujeitos e o seu papel criativo na história. Nesse sentido, convém retomar as palavras do autor:

Embora as pessoas se encontrem, de saída, numa sociedade estruturada já de determinada maneira, a constituição histórica das classes depende da experiência das condições dadas, o que implica tratar tais condições no quadro das significações culturais que as impregnam. E é na elaboração dessas experiências que se identificam interesses, constituindo-se então coletividades políticas, sujeitos coletivos, movimentos sociais. (E certamente, na medida em que tais movimentos se constituem um agente ativo na formação social, mesmo aquela 'estrutura já dada' é também produzida pelas interações e lutas de classe) (SADER, 1988, p. 44-45, grifos do autor).

As noçóes de política e de espaço público, formuladas por Hannah Arendt, também sáo caras a este artigo ao apontar para a capacidade criativa da açáo humana. Para Arendt, política náo se define pela força, mas pela participaçáo em um mundo comum, isto é, a política é o próprio mundo formado entre os homens. Nesta concepçấo, a liberdade e a igualdade sâo fundamentais para que ocorra a política, atividade humana de maior grandeza. Somente nestas condiçóes é possível constituir um espaço público, onde os homens

9 Outros autores também são relevantes na obra de Sader (1988), tais como Antônio Gramsci e Cornelius Castoriadis. 
podem usar de sua qualidade da fala para se expressar como nenhum outro, bem como podem agir, o que lhes permite criar algo inesperado, inédito. Evidentemente, neste sentido, privar homens deste espaço, por meio de açóes sistemáticas de agentes privados significa a supressão da política ${ }^{10}$ ou a desconstrução de espaços públicos.

Política é estar no mundo, colocar-se em público diante da pluralidade e ter capacidade de agir e discursar. A açáo, deste modo, é uma atividade fundamental dos homens e corresponde à condiçáo humana da pluralidade: "[...] ao fato de que os homens, e não o homem, vivem na terra e habitam o mundo" (ARENDT, 2010, p. 8). Em um mundo plural, os homens sáo iguais, por isso, podem se distinguir:

A pluralidade humana, condição básica da ação e do discurso, tem o duplo aspecto da igualdade e da distinção. Se não fossem iguais, os homens não poderiam compreender uns aos outros e os que vieram antes deles, nem fazer planos para o futuro, nem prever as necessidades daqueles que virão depois deles. Se não fossem distintos, sendo cada ser humano distinto de qualquer outro que é, foi ou será, não precisariam do discurso nem da ação para se fazerem compreender. Sinais e sons seriam suficientes para a comunicação imediata de necessidades e carências idênticas (ARENDT, 2010, p. 219-220).

A ação e o discurso se caracterizam como duas categorias centrais no pensamento político de Arendt. Somente a ação permite ao homem realizar o inesperado. Através dela, o homem "[...] é capaz de realizar o infinitamente improvável" (ARENDT, 2010, p. 222) e isso "[...] só é possível porque cada homem é único, de sorte que, a cada nascimento, vem ao mundo algo singularmente novo. Desse alguém que é único pode-se dizer verdadeiramente que antes dele não havia ninguém" (ARENDT, 2010, p. 222-223). Uma vida sem açáo e sem discurso seria, por assim dizer, morta para o mundo, uma vez que deixa de ser vivida entre os homens".

10 É importante lembrar que Arendt contrapõe ao espaço público, a esfera privada, símbolo de que o ser humano tem um lugar seu no mundo. Segundo Arendt, para os gregos antigos, possuir um espaço privado não estava relacionado ao acúmulo de riqueza, mas ao fato de o homem possuir um lugar seu, o que lhe dava sustentação para o pertencimento a um corpo político: "originalmente, a propriedade significava nada mais nada menos que o individuo possuía seu lugar em determinada parte do mundo e, portanto, pertencia ao corpo político, isto é, que chefiava uma das familias que constituíam em conjunto com o domínio público" (ARENDT, 20I0, p. 76).

11 " $A$ importância de ser visto e ouvido por outros provém do fato de que todos veem e ouvem de ângulos diferentes" (ARENDT, 2010, p. 70). 
Como possui um caráter revelador do agente juntamente com o ato, a açáo necessita para sua plena manifestaçáo da luz do espaço público. A perda do espaço público faz com que a ação perca "[...] seu caráter específico e torna-se um feito como outro qualquer" (ARENDT, 2010, p. 225). Isso ocorre sempre que o estar juntos se desfaz, quando os homens se colocam uns contra os outros ou se recolhem no mundo privado. Ainda de acordo com a autora, qualquer atividade humana é condicionada pelo fato de os homens viverem juntos, mas a ação "[...] náo pode sequer ser imaginada fora da sociedade dos homens" (ARENDT, 2010, p. 26).

É importante também esclarecer a centralidade da noção de projeto político para esta pesquisa. É por meio dessa chave analítica que abordamos os diversos padróes e configuraçóes políticas presentes no município de Sarandi. Um projeto político é compreendido como uma matriz política, social e cultural de onde diferentes sujeitos buscam referências para sua ação, mas também, ao mesmo tempo, as modificam e ressignificam. Segundo Dagnino (2004), um projeto político consiste em um conjunto de valores, crenças, interesses e representaçôes do que deve ser a vida em sociedade e que orienta a açáo política de diferentes sujeitos.

De acordo com Dagnino, Olvera e Panfichi (2006), esta noção pretende enfatizar a intencionalidade como elemento importante da política, considerando o papel do sujeito e da açáo humana como dimensóes essenciais da política. Esta noção apresenta a compreensão de que a política também é um terreno estruturado por escolhas expressas nas açóes dos sujeitos, "[...] orientadas por um conjunto de representaçóes, valores, crenças e interesses" (DAGNINO; OLVERA; PANFICHI, 2006, p. 39).

Nesse sentido, um projeto político comporta um vínculo indissolúvel entre cultura e política, de modo que "[...] não se reduzem a estratégias de atuação política no sentido estrito, mas expressam, veiculam e produzem significados que integram matrizes culturais mais amplas" (DAGNINO; OLVERA; PANFICHI, 2006, p. 39). Assim, da mesma forma que os sujeitos sociais se apoiam em configuraçóes culturais macrossociais, eles também inserem novos elementos que podem transformar e reinterpretar o repertório cultural e as práticas da sociedade.

Outra característica importante dessa noçáo é que ela não se restringe a açóes sistematizadas no campo político institucional, mas comporta uma série 
de sujeitos sociais, temas e formas de ação política nas mais diversas instâncias societárias. Dagnino, Olvera e Panfichi salientam que

Essa flexibilidade da noção aqui adotada permite que ela seja capaz de dar conta da multiplicidade e diversidade dos sujeitos políticos envolvidos no processo de construção democrática e das suas diferentes formas de ação política, com frequência desconsideradas nas análises desse processo (DAGNINO, OLVERA E PANFICHI, 2006, p. 40).

Nesse sentido, um projeto político é um conjunto mais ou menos organizado de ideias, interesses, valores e crenças que norteiam a açáo dos distintos grupos na luta pela hegemonia ${ }^{12}$. É importante salientar ainda que os projetos políticos não sáo blocos fechados, da mesma forma que os grupos que os formulam náo são impermeáveis e em absoluta oposição a outras vertentes. $\mathrm{Na}$ realidade, a forma como os projetos políticos são produzidos, incorporados e transformados podem oscilar e, em alguns casos, mesmo mesclar elementos de distintas matrizes político-culturais.

Assim, é possível que alguns sujeitos incorporem radicalmente um projeto democrático participativo e que rejeitem outras formas de ação, tomadas como conservadoras para este grupo. Por outro lado, também é possível a incorporação radical de outro projeto político. No entanto, além da possibilidade da construção de outros projetos políticos, é possível a incorporação em diferentes graus de elementos destes projetos já instituídos, de modo que a ação de um amplo grupo de sujeitos pode alternar por diferentes concepçóes de acordo com o contexto com que se defrontam.

Marcelo K. Silva (2006) aborda a questáo da sociedade civil, sua relação com o Estado e demonstra que ela náo é um ator homogêneo, predisposta, a priori, nem para democratizar nem para reproduzir a cultura autoritária. Segundo o autor, não é possível, de partida, concebê-la como democratizante ou como reprodutora das desigualdades sociais. Silva (2006) salienta que

12 Para os autores, atualmente, na América Latina, dois principais projetos políticos encontram-se em disputa. De um lado temos um projeto herdeiro da tradição autoritária latino-americana, que se reveste de traços neoliberais, e por outro um projeto democrático-participativo, herdeiro da luta dos movimentos sociais. Por serem projetos políticos em disputa, o próprio processo de democratizaçãonão é concebido como contínuo ou circunscrito ao Estado, mas como construção: "Um processo complexo, desigual e contraditório, distinto em forma e ritmo em cada nação, determinado tanto pelas especificidades históricas locais, regionais e nacionais, como pelas condições criadas pela globalização e pela intervenção de agências multilaterais, redes internacionais de ONG, e movimentos sociais alternativos" (DAGNINO, OLVERA; PANFICHI, 2006, p. 7). 
O conceito de sociedade civil delimita um campo heterogêneo de atores sociais, os quais podem apresentar os mais diversos tipos de representações e práticas em relação à democracia (divergindo, geralmente, até mesmo sobre o seu significado). A sociedade civil se caracteriza, assim, tanto pela diversidade quanto pela mudança, fazendo com que não haja uma "natureza" preestabelecida, mas sim um contínuo processo de construção, reprodução e transformação dos atores, a partir das configurações geradas pelo campo de relações que estabelecem" (SILVA, 2006, p. 175) 13 .

De acordo com o autor, há análises que identificam na sociedade civil virtudes essencialmente democratizantes e outras que questionam as supostas potencialidades de democratizaçáo da sociedade civil e passam a identificá-la com marcados traços clientelistas, autoritários e de baixa densidade participativa. Nesse sentido, segundo o autor,

[...] algumas análises que adotam uma perspectiva crítica em relação às potencialidades democratizantes da "sociedade civil" também apresentam um viés "essencialista", mas de sentido oposto. Ou seja, contra o pressuposto do inerente caráter democrático da sociedade civil, é assumido o pressuposto da sua insignificância ou, em outras versões, da sua influência negativa à democracia. Ou seja, de "pólo da virtude", que encarnaria a positividade e assumiria o protagonismo do processo de construção democrática, a sociedade civil se torna um espaço da reprodução das desigualdades, de tensionamento das instituições democráticas elou de esvaziamento da própria política [...] (SILVA, 2006, p. 159).

Diante de tais problemas, Silva busca superar esses "essencialismos maniqueístas" por meio de uma abordagem relacional e historicamente situada que, ao contrário de afirmar "determinadas características intrínsecas", leva em consideraçáo

[...] que não existe uma relação unívoca entre sociedade civil e construção democrática. Ao contrário, esta relação apresenta diferenciações de acordo com os distintos contextos locais analisados, os quais constituíram, ao longo de suas trajetórias, configurações locais específicas, nas quais e pelas quais se definem as relações entre os atores da sociedade civil e a democratização da gestão pública (SILVA, 2006, p. I6I).

13 Ao longo dos anos 1990, prosperou uma literatura cujos principais expoentes foram Sérgio Costa e Leonardo Avritzer. Tais sustentaram que a sociedade civil seria, grosso modo, por meio das associações civis voluntárias, independente tanto do sistema financeiro como do Estado, capaz de adensar e ampliar os problemas provenientes do mundo da vida e tematizá-los no espaço público, promovendo o alargamento da democracia, isto é, democratizando a própria democracia. Uma crítica a este modelo teórico pode ser encontrada em Gurza Lavalle (200I). 
Portanto, as possíveis características das associaçóes e dos movimentos alocados na sociedade civil não podem ser atribuídas a priori. Ao contrário, para caracterizá-la é necessário investigar levando em consideraçáo o contexto histórico em que ela se insere, bem como o conjunto de referências sociais e políticas incorporadas pelos diversos sujeitos sociais.

Goetz Ottmann (2006) faz uma interessante análise do processo de democratizaçáo ao buscar compreender o espaço que se abre entre o tradicional e o moderno. $\mathrm{O}$ autor procura demonstrar que embora a interpretaçáo da persistência de práticas tradicionais no sistema político brasileiro tenha muito a dizer, ela deixa

De examinar o espaço que se abre entre os pontos de referência do 'tradicional' e do 'democrático'. Mais importante, deixa de observar o quanto essas práticas políticas tradicionais estão se transformando nos contextos de democracia participativa, no qual de fato figuram, para melhor ou para pior (OTTMANN, 2006, p. 155).

Ottmann sustenta que o processo de democratização não elimina práticas como clientelismo e patronagem política, mas tende a incorporá-las e transformá-las. Segundo o autor, as transiçóes democráticas, iluminadas pelos ideais universalistas da democracia e de adoçáo de procedimentos legal-racionais na administraçáo pública, defrontam-se com a desigualdade econômica e com a pobreza, o que faz com que o acesso aos direitos de cidadania passem a ser constantemente negociados: "Dessa forma, [afirma o autor] náo é de surpreender que os estudos de caso aqui apresentados indiquem que a democratizaçáo das políticas municipais que envolvem a reduçáo da pobreza e das relaçóes de dependência tende a requerer uma rede de assistência social organizada pelo Estado" (OTTMANN, 2006, p. 157).

Ottmann busca desconstruir a imagem de que as noçôes de clientelismo, patronismo e outros correlatos seriam tradicionalmente ligadas a práticas arcaicas encontradas em países em desenvolvimento. Assim, o autor insere a noção de clientelismo em um contexto de cidadania mediada, ou seja, "[...] num contexto político que não se pauta por regras efetivamente universalistas o acesso à cidadania é constantemente negociado" (OTTMANN, 2006, p. 158). Deste modo, onde os direitos de cidadania não estáo disponíveis para a população de baixa renda, eles são perseguidos por alguma forma de ação coletiva. Desse modo, a busca pela patronagem política passa a ser vista como 
uma estratégia desenvolvida pela população pobre para acessar direitos e não como uma incapacidade de raciocínio desta. Segundo Ottmann,

A patronagem política (uso de verbas pelos políticos para concessão de benefícios às suas bases eleitorais) certamente constitui um aspecto central da maioria dos sistemas políticos modernos, mas em lugares onde os direitos de cidadania não são universais essa prática se revela ainda mais essencial, na medida em que conforma uma importante rede de assistência social. Assim é que não faz muito sentido conceber o clientelismo latino-americano em termos de um "familismo amoral" banfieldiano: num contexto de pobreza em massa e de direitos de cidadania negociados, a mobilização e a inclusão sociopolíticas dos pobres tende a envolver alguma forma de política de bem-estar (OTTMANN, 2006, p. 159).

O trabalho de Ottmann nos remete à compreensão de que a população pobre se vale das estratégias de que dispóe para conquistar benefícios, ou, em outras palavras, direitos de cidadania. Assim, manter vínculos clientelistas com determinados políticos ou procurar ampliar o máximo possível sua rede de relaçóes seriam estratégias utilizadas por moradores pobres para obter e/ou manter seus benefícios, mesmo que o poder mude de máos. Outra estratégia apontada pelo autor, com base em seu estudo de caso, é a opçáo por neutralidade política praticada por líderes comunitários:

Esse era o caso do presidente de associação de bairro Rodrigo Leite, que tinha absoluta convicção da importância de não tomar partido de nenhum dos lados. Caso solicitado a dar apoio, ele o daria a ambos os lados a fim de não ser associado a nenhum dos dois: "não se deve apoiar um só candidato, porque se ele não for eleito o bairro vai acabar sem benefícios. É preciso deixar que os moradores façam suas próprias cabeças”. Dessa maneira, Rodrigo buscava negociar o melhor acordo possível para a sua comunidade (OTTMANN, 2006, p. 163).

Foi, com efeito, a partir da apresentação e análise deste marco conceitual que realizamos a fase empírica da pesquisa. Entre as técnicas de investigaçáo, valemo-nos de um trabalho de campo de natureza exploratória, entre o primeiro semestre de 2011 e o segundo de 2012. Nos primeiros meses de 2012, também realizamos entrevistas semiestruturadas com 27 presidentes ou membros de associaçóes de moradores, entre eles o presidente da Uniáo Sarandiense de Associaçáo de Moradores (UNISAM). As entrevistas foram gravadas e integralmente transcritas. Todo o esforço analítico foi concentrado para compreender a complexidade do fenômeno estudado, buscando fugir dos esquemas e das respostas fáceis. Assim, após essa breve revisão 
bibliográfica, passamos a apresentar algumas consideraçōes sobre o associativismo sarandiense.

\section{Projeto político democrático participativo}

O município de Sarandi se localiza no norte do Estado do Paraná e faz conurbaçáo com Maringá, município que sedia a regiáo metropolitana, criada em 1998. Embora a Regiāo Metropolitana de Maringá (RMM $\left.{ }^{14}\right)$ seja composta de 25 municípios, efetivamente apenas Maringá, Paiçandu e Sarandi sáo contíguos. Enquanto Maringá se caracteriza como uma cidade bem estruturada com equipamentos e serviços, as cidades de Sarandi e Paiçandu sáo caracterizadas pela falta de planejamento urbano e pelo custo de vida mais barato, o que cria condiçóes para que a populaçâo de baixa renda consiga se assentar nesses municípios (RODRIGUES, 2004).

Sarandi se caracteriza como uma cidade predominantemente de populaçáo com baixa renda e por problemas na área da infraestrutura urbana, educaçáo, saúde, moradia e segurança. Com vários problemas sociais, surge um número significativo de associaçóes de moradores e de outras formas de organização coletiva com a intençáo de enfrentar, de alguma forma, tais problemas $^{15}$. Nesse artigo, limitamo-nos a realizar uma análise sumária do associativismo de moradores sarandienses, que se encontra estruturado em distintos padrôes de atuaçáo.

Assim, uma parcela do associativismo sarandiense busca inspiraçáo para sua atuaçáo no que podemos chamar de tradiçáo dos movimentos sociais brasileiros ${ }^{16}$. À luz de uma linguagem dos direitos e da igualdade social, este setor realiza uma reinterpretação dos problemas sociais e forja um padráo de açáo coletiva capaz de desafiar a ordem estabelecida e criar um espaço público onde pode projetar suas existências, seus dramas, suas vidas.

Essa vertente associativa começou a gestar ainda nos anos 1990 quando a cidade enfrentou uma crise de abastecimento de água, período em que

14 A Região Metropolitana de Maringá foi criada pela Lei Estadual n. 83/98 e constituida inicialmente pelos municípios de Maringá, Sarandi, Paiçandu, Marialva, Mandaguaçu, Mandaguari, Ângulo e lguaraçu. Leis complementares incorporaram outros municípios, totalizando, em 2010, 25 ao todo e reunindo mais de 700.000 pessoas (TONELLA, 2011, p. 5).

15 Para uma análise mais detida das dificuldades do município sarandiense, ver Priori (2013).

16 Ver Sader (1988) e Feltran (2005). 
cresceram os apelos de privatização por parte da prefeitura municipal. Nesse contexto, emergiu um movimento popular que passou a questionar a soluçáo privatista para "o esvaziamento das torneiras". Padres ligados à teologia da libertação, grupos de jovens da pastoral da juventude, militantes de esquerda, estudantes secundaristas, associaçóes de moradores passaram a enfrentar o que consideravam prejudicial ao munícipio.

$\mathrm{O}$ prefeito desejava vender o sistema municipal de água e inclusive teve o projeto de privatizaçáo aprovado na câmara dos vereadores. No entanto, a população se organizou e depois de muitas manifestaçóes, protestos, passeatas conseguiu reverter o processo de "venda da água". Nesse contexto, é possível afirmar que se inaugura em Sarandi uma nova forma de organizaçáo popular, caracterizada pela independência e pela própria recriaçáo política.

Tendo como característica marcante a emersáo pública popular e a contestaçáo da política instituída, a partir de entáo se forjou em Sarandi o que podemos chamar de um campo político democrático-participativo. $\mathrm{O}$ conceito de campo político, segundo Feltran, seria um espaço simbólico em que as iniciativas movimentistas se mostram e se apoiam, o que dá sustentaçáo e projeta as lutas sociais para o espaço público. Segundo o autor, sem campos políticos a ação movimentista é como se fosse projetada no vazio ${ }^{17}$ (FELTRAN, 2005, p. 209).

A inauguraçáo desse projeto político forjado desde a sociedade civil ocorre com essas jornadas contra a privatização do sistema de água e permanece vivo ainda hoje. É importante mencionar que este projeto náo se limitou a atuar desde a sociedade civil, mas passou também a disputar e ocupar cargos no Estado, por meio da eleição de vereadores e até mesmo do prefeito municipal Aparecido Spada, pelo Partido dos Trabalhadores.

Embora não seja hegemônica, essa vertente segue presente em Sarandi por meio de algumas associaçóes que têm politizado questóes sociais e fomentado a criaçáo de espaços públicos, por meio da pressáo sobre o legislativo e o executivo municipal. É o caso, por exemplo, da associação de Felipe ${ }^{18}$ que

17 De acordo com Feltran "sem espaços na sociedade para que possam constituir campos políticos [...] em que se mostrem e se apoiem, as iniciativas movimentistas são semelhantes a imagens projetas no vazio; não se realizam" (2005, p. 209).

18 Ao longo da pesquisa, foram realizadas entrevistas semiestruturadas com os presidentes de Associações de Moradores do Município de Sarandi-PR e integralmente transcritas. As citações obedecem às regras de citações bibliográficas diretas, e os nomes dos entrevistados são fictícios. 
tem rejeitado qualquer parceria com os governantes que venha lhe cercear a liberdade de atuaçáo. Náo se trata de recusar o diálogo terminantemente, mas de náo permitir que o atrelamento aos governantes prive a associaçáo do direito de denunciar o que julgar incorreto. Segundo Felipe, é importante ter um bom relacionamento com a política institucional, todavia "náo ficar preso a eles, né". Felipe justifica sua posição com base na experiência de outras associaçóes que, na sua avaliação, acabam por descaracterizar o papel de associaçáo, ao se tornarem parceiras dos governantes:

Porque às vezes aqui eu conheço bastante associação que, em vez de desempenhar seu papel de associação de moradores, faz parceria com o governante. E aí não pode reivindicar nada, daí fica preso a ele, cê não tem nada. Nós não podemos ser assim, nós não podemos. Nós temos que fazer um trabalho junto, mas sem tá preso a eles. É que, de repente, até eles vêm aqui e fala: "vou fazer isso aqui, mas você passa pro meu lado". Não, nossa associação não, a nossa graças a Deus nós somos independente. É, tem, assim, é, vários, membros de vários partidos dentro da associação. Mas nós não somos ligados a ninguém, entendeu? Então nós temos a liberdade de cobrar aquilo que o bairro precisa, aquilo que a população precisa. Então nós não temos medo disso, porque nós não somos preso a eles. Agora se eu faço uma aliança com eles, se comprometendo, como é que eu vou cobrar depois? (Felipe, entrevista, 2012).

É importante salientar que essa independência náo significa ruptura com o Estado, tampouco com a política institucional e mesmo com partidos políticos. Trata-se, na realidade, de um projeto político que, tanto na sociedade como no Estado, opóe-se a práticas que se encerram em soluçóes personalistas e privatistas. Nesse sentido, a associaçáo de Felipe tem realizado um contundente trabalho de mobilizaçáo, fiscalizando, denunciando e cobrando soluçóes das autoridades, seja executiva ou legislativa.

Assim, é possível falar de uma vertente de açáo coletiva que sustenta sua prática pelo estabelecimento do conflito, pela fundaçáo de espaços públicos e pela reivindicação de direitos. Essa vertente, como tentamos demonstrar, nâo está limitada às fronteiras da sociedade civil, mas permanece em contínua relaçáo com o Estado, seja para exigir que ele atenda os direitos da populaçáo, seja para ocupá-lo, por meio de eleiçóes. Em seguida, apresentamos outra vertente associativa que tem optado pela negociaçáo e pela parceria, muitas vezes privada, com políticos tradicionais. 


\section{Conciliação e parceria: um projeto governista}

$\mathrm{O}$ associativismo sarandiense tem passado por mudanças à medida que boa parte das associaçóes adotou predominantemente uma postura de natureza conciliatória e governista. Assim, certos de que a supressáo do conflito é mais benéfica, a aposta de boa parte das lideranças associativas recentes tem sido pela parceira com o governo municipal. Em meados de 2010, um grupo de associaçóes apoiados pelo prefeito municipal, Carlos Alberto De Paula Jr. (PDT), organizou uma chapa para disputar a direção da Uniāo Sarandiense de Associaçóes de Moradores (UNISAM) e acabou vencendo as eleiçóes.

Esta chapa se contrapunha a diretoria da época, a qual atuava de forma predominantemente conflitiva, inclusive participando das manifestaçóes pela cassação do ex-prefeito Milton Martini ${ }^{19}$ (PP). A proposta dessa nova chapa era romper com o padrâo de oposiçáo municipal e se aproximar do prefeito. De acordo com Walter, a sua chapa procurou deixar claro ao prefeito que desejavam estar perto dele para que pudessem mostrar ao prefeito a realidade dos bairros:

Assim, na realidade, a gente deixou bem claro que a gente queria tá perto, todo momento a gente queria tá perto. [...] Ou a gente é conversa e se adapta à realidade, a gente busque aquele meio de chegar, falar, a gente precisa de diálogo, e isso que a outra administração não tinha, a concorrência não teve. E a gente propôs o seguinte, a gente quer tá perto, a UNISAM quer tá perto. Foi essa a nossa proposta desde o início com o De Paula (Walter, entrevista, 2012).

Assim, essa chapa se configura, como reconhece Ivani (entrevista, 2012) como o grupo do prefeito: "é na verdade a nossa chapa era do prefeito". Contudo, é importante salientar que a aposta na parceria com o chefe do executivo náo se trata simplesmente de uma manobra manipuladora do prefeito. O que ocorre, na verdade, é uma confluência de opinióes e crenças sobre como atuar politicamente, evidentemente bem distinta daquela apresentada no item anterior.

19 Martini foi eleito em 2008, tendo como vice-prefeito Carlos Alberto de Paula Jr. Depois de denúncias de corrupção e da pressão popular, com especial participação da UNISAM. Martini foi cassado pela câmara de vereadores numa longa sessão legislativa iniciada no dia $1^{\circ}$ e encerrada apenas na madrugada do dia 2 de março de 2010. No mesmo dia. De Paula tomou posse como prefeito municipal. 
Eleita com o apoio da máquina municipal, a UNISAM passa a fundamentar sua açáo num outro quadro de referência. Enquanto a gestăo passada se pautava por uma lógica conflitiva, a atual opta invariavelmente pela negociação. Josué, por exemplo, defende o que ele chama de "agir dentro da lei", em outras palavras, rejeita estratégias como fazer greves, protestos, fechamento de ruas. Sua posiçáo é de que tudo pode ser resolvido na conversa, em vez de fazer o que ele classifica como "baderna". Nesse sentido, configura-se um projeto que se contrapóe ao democrático e popular:

[...] eles queria que a associação fosse pra cima, fosse fazer greve, fazer fechamento, baruIho. Que a gente aí no passado até político andou levando umas cassetada aí, processo aí, por esse tipo de coisas. Eu acho que a linha é sempre dentro da lei, agir dentro da lei é a melhor coisa do mundo. E a primeira coisa que eu sempre tive comigo é a conversa, conversa uma, conversa duas, conversa três, por que não a quarta? Aí a linha é diferente. Então a nossa linha era essa, não ter baderna. Então cê viu que Sarandi ela parou com baderna, Sarandi era noticiado em qualquer é jornal, Sarandi fechou tal lugar, Sarandi fez não sei o quê, acabou isso. E a cidade começou a andar (Josué, entrevista, 2012).

Josué narra com orgulho que a cidade começou a desenvolver-se quando a UNISAM deixou de questionar e passou a apoiar a governo municipal. Neste sentido, fica evidente o deslocamento de sentido na atuaçáo da UNISAM. $\mathrm{Na}$ percepçâo dele, a aposta na parceria com o prefeito deu certo, e hoje a cidade se encontra bem melhor que antigamente ${ }^{20}$.

Assim, esta vertente acaba por desenvolver uma postura governista à medida que compreende que a associaçáo de moradores ou mesmo a UNISAM é "uma extensão da prefeitura" - para usar a expressão de Ivani - e, portanto, deve zelar sempre pelo bom relacionamento com o executivo municipal. A presidenta defende que as associaçóes sejam como que "office boys" da prefeitura, servindo de intermediários entre o prefeito e o povo e levando as necessidades desses para o executivo ${ }^{21}$.

20 Ele narra como tem sido o relacionamento com o prefeito: "O De Paula ele falou assim que precisava da UNI$S A M$ pra trabalhar e fazer com que a cidade viesse assim a desenvolver. E a gente deu essa credibilidade pra ele, tanto que você viu ai hoje cidade aí hoje, a cidade não tem essa buraqueira mais, a cidade hoje tem uma linda UPA, construindo o hospital municipal. Colégio sendo ampliado lá no Vale Azul, asfalto no Vale Azul, asfalto no Alvamar, entendeu? [...] E assim a gente tinha aquela proposta, se tá fazendo lá o meu tá próximo. Essa é a esperança do pobre, né. O dia de amanhã vai ser melhor. Se tá fazendo vai melhorar e vai ser rápido" (Josué, entrevista, 2012).

21 "Eu costumo dizer assim que nós somos uma espécie de office-boys da prefeitura. Que a gente pega e leva, faz a entrega dos problemas lá. Então, é, teria que ser mais valorizado o presidente de bairro porque, na verdade, 
$\mathrm{Na}$ mesma direção, Anderson entende que, mesmo sem perder a autonomia, a associação de moradores deve evitar ser oposição, devido aos riscos que esta postura atrai:

[...] eu não concordo com a oposição, porque a oposição, às vezes, demais, ela atrapalha, ela atrapalha. [...] Muita oposição não é legal. E daí o prefeito, o político, o vereador ele vai começar a ter uma rixa com você e você como presidente de bairro, com certeza ele vai te atender menos, na prefeitura. Você sendo parceiro dele não, ele vai te atender mais vezes (Anderson, entrevista, 2012).

De fato, essa opção pela amizade com o governo trata-se claramente de uma estratégia de ação ancorada na conquista de benefícios imediatos. $\mathrm{O}$ raciocínio é mais ou menos assim: "em troca do meu apoio político a você, quero que você atenda o meu bairro". No entanto, essa estratégia apresenta um déficit democrático participativo, visto que a mobilizaçáo popular, a tematizaçáo pública dos direitos e o protagonismo social cedem lugar a uma soluçáo privada, precária e com certo tom clientelista, pois se estabelece uma relação de troca entre o gestor e o morador.

A configuração dessa vertente associativa permite depreender um padrão de ação coletiva distinto do que apresentamos anteriormente. Enquanto aquela se vale de critérios públicos, conflitivos, rejeitando a negociaçáo personalizada, essa vertente, numa postura de negaçáo ao perfil do primeiro grupo, opta pela amizade, pela rejeição da oposiçáo ao poder público, pela amenizaçáo do conflito e pela resoluçáo por meio da conversa. Desse modo, é possível afirmar que perpassa por este grupo um padráo mais restrito de democracia e mesmo menos participativo, já que em vez de mobilizar a população para cobrar o poder municipal, as redes pessoais e a negociaçáo dos gabinetes sáo consideradas mais eficazes.

Assim, podemos identificar no interior da sociedade civil nos limites territoriais de Sarandi-PR, um padráo de açáo coletiva - o que temos chamado de projeto político - de natureza participativa, reivindicatório, conflitivo, mas também um projeto conservador, governista e elitista do ponto de vista da

a associação de moradores é uma extensão da prefeitura. E se o prefeito coloca isso na cabeça ele poupa até uma quantia de trabalho, de funcionários, de tudo. Porque cê quer saber de um problema que tem aqui, você chega no presidente de bairro, ele vai saber do problema" (Ivani, entrevista, 2012). 
construção democrática. Todavia, é possível identificar ainda atores que não se limitam as estratégias de apenas um destes tipos opostos, mas que oscilam entre um e outro, ora tendendo mais a negociaçáo, ora mais ao conflito.

\section{Entre a negociação e o protesto - seleção estratégica}

Em parte significativa dos presidentes de associaçáo de moradores de Sarandi, uma forma específica de açáo chama atenção justamente por não expressar com convicçáo nem o padráo democrático participativo nem o governista, ou melhor, por expressar os dois em momentos distintos de sua ação. De fato, cabe ao analista estar atento às sutilezas das tramas sociopolíticas, para evitar a reduçáo a um ou outro polo da luta política e para náo cair na armadilha de caracterizar tais grupos em alguma forma de esquizofrenia ou anomalia. De fato, tal configuração nos levou a debruçar analiticamente sobre esta problemática e desenvolver formas de análise capazes de expressarem as singularidades desses grupos. Dentro desse esforço que elaboramos a noção de seleção estratégica.

Observa-se, de fato, no discurso de um grupo de presidentes, uma transiçáo entre os projetos políticos instituídos em Sarandi. Isso náo significa, todavia, que eles considerem suas açóes práticas contraditórias. Segundo suas percepçóes, a forma como fundamentam suas açóes é coerente com as demandas de seus bairros e para alcançá-las mobilizam os repertórios de estratégias que têm a sua disposição. Nesse sentido, sua atual opção por uma atuaçáo mais combativa ou mais conciliatória pode ser modificada no futuro, desde que o contexto se modifique e exija novas estratégias. Trata-se de uma tensáo e de uma reavaliaçáo contínua em que referências distintas são analisadas, examinadas e consideradas suas possibilidades de sucesso. Tal contexto acaba por resultar num padráo de atuaçáo específico de parte das associaçóes de moradores de Sarandi, ou seja, a seleçâa estratégica.

O caso do presidente de associação Joel, por exemplo, deixa transparecer este trânsito, miscibilidade e seleçáo entre distintos projetos políticos. A referência principal dele é a negociaçáo via amigos e conhecidos, mediadores que podem influenciar no atendimento de suas demandas. Todavia, caso essas redes privadas falhem, ainda há à sua disposiçáo a possibilidade do estabelecimento do conflito e do embate público, quando a populaçáo pode ser mobilizada para conquistar a "melhoria pro bairro". Neste caso, os principais mediadores seriam as lideranças dos movimentos sociais do município. 
Próximo afetivamente a lideranças importantes do campo conservador prefeito e secretários de município -, Joel demonstra enxergar nos "pedidos" ao prefeito a melhor soluçáo para as questóes do bairro:

Respeito ele e toda a vida eu conversei com ele, que eu vou pedir alguma coisa, ele nunca falou não pra mim. Ele só pediu um tempo, porque Sarandi tem muito problema, ele falou: "Oh, Antônio, me dá um tempo que eu vou tentar resolver da melhor maneira possível, ceis não vão se arrepender". Eu, eu, no que eu pedi pra ele até hoje, tanto como o secretário da fazenda também, que é muito meu amigo, eu nunca ouvi não, não, até hoje não, não, sempre quando pediram um tempo e sempre colaboraram pra me ajudar (Joel, entrevista, 2012).

A narrativa de Joel indica o que ele concebe como melhores alternativas para solucionar os problemas sociais que tanto o afligem. Ele busca a mediaçáo de suas demandas em vínculos privados: suas amizades, a palavra de gestores públicos e mesmo do prefeito são formas razoáveis de conseguir atendimento para o bairro. Todavia, se for necessário, ele não se opóe à realização de protestos - forçar um conflito público -, pois em alguns casos náo resta alternativa à populaçáo:

É, porque hoje muitas vezes você vê certas situação, então é direito também manifesto, de panelaço que o pessoal fala, cara-pintada. Então muitas vezes o que acontece na cidade é isso, se não fizer um manifesto, parece que infelizmente os políticos não apoiam, [...] eles não escutam e a gente tem que fazer, se for preciso fazer sim, e eu acho que como presidente, estou disposto, eu apoio (Joel, entrevista, 20I2).

Essa formulação de Joel possivelmente é inspirada nas lutas populares conflitivas, em toda mobilização democrático-participativa realizada na cidade de Sarandi e mesmo nas lutas de dimensão estadual e nacional. Nesse sentido, ele deixa entrever que algumas causas somente podem ser conquistadas por meio do conflito publicamente estabelecido. Trata-se de uma estratégia que pode ser utilizada em casos específicos. Quando seu bairro, por exemplo, enfrentou problemas com o asfalto, a associaçáo propôs a organizaçáo de um protesto; Joel náo se opôs, mas pediu um tempo para "conversar com alguém" e, graças à sua amizade dentro da prefeitura, não foi necessária a manifestaçáo:

Teve já alguma coisa pra sair, inclusive eu era vice-presidente ainda, teve um protesto já iniciado no bairro. Eu perguntei, cheguei no pessoal, vamos dizer assim, no líder, que tava fazendo isso, pedi pra ele que me desse uns dias de prazo, que eu ia conversar com alguém. Porque era sobre o recapeamento do nosso bairro, uma ruas que não tinham nem 
condição de circular. Ele me deu esse prazo, então não teve protesto. Eu fui lá, conversei com o pessoal, que são muito meus amigos dentro da prefeitura, não vou mentir. E a gente conseguiu essa melhoria de trazer o recapeamento pra onde precisava e começou a rebaixar também a iluminação pública [...] (Joel, entrevista, 20I2).

Assim, Joel (entrevista, 2012) se mostra satisfeito com os serviços que a prefeitura vem prestando, apesar de pensar que "[...] dava pra fazer um pouquinho mais, eu acredito que dava". Ao mesmo tempo em que usa expressóes como "pedir", "conversar com alguém", "ajuda”, Joel parece mudar de registro na reflexão política e social - como a simpatia pelos atos públicos - e fala em cobrar direitos e lutar pelo bairro. Desse modo, ele mescla elementos mais combativos e outros mais conciliatórios, como nesse trecho de sua entrevista, quando num primeiro momento fala em "cobrar" e "reivindicar" para, em seguida, afirmar a "ajuda" da prefeitura:

[...] A gente tem cobrado, a gente tem falado, a gente tem explicado, é, a gente tem reivindicado junto ao prefeito a melhoria pro bairro, aconteceu já alguma coisa sim. Então o povo agora tá começando a brigar um pouco mais, desde os três anos que eu fiquei de vice, agora sou o presidente da associação, a gente vem reivindicado isso, eu não vou dizer que a gente não teve alguma ajuda, que teve sim (Joel, entrevista, 2012, grifos nossos).

Discursivamente Joel busca romper com um padrão conservador de atuaçáo associativa, mas no momento seguinte regressa a este mesmo padrão. Nesse sentido, a disputa de distintos projetos políticos ocorre nas representaçóes sociais e na ação dele. Em seu caso, tal problemática parece equilibrar-se, através da constituição de um repertório de estratégias de açáo para conquista de distintas demandas. Nessa direçáo, é o grau de dificuldade e a possibilidade ou não de negociaçáo pessoal que determinará se é preciso recorrer ao conflito.

O caso de Cléber, por sua vez, também é ilustrativo dessa apropriação seletiva de elementos de distintos projetos na prática associativa em Sarandi. Ao contrário de Joel, Cléber tem um histórico de participaçáo em mobilizaçóes populares passando por lutas históricas no município, como a empreitada contra a privatizaçáo da água e pela cassaçáo do prefeito municipal Milton Martini $^{22}$, além de muitas outras de menor destaque em nível municipal.

22 A luta contra a privatização do Departamento de Água e Esgoto de Sarandi foi uma exitosa luta levada a cabo pelos movimentos populares entre os anos de 1998 e 1999. Este foi um importante momento de consolidação dos movimentos sociais de Sarandi e de fortalecimento de novas lideranças de esquerda. A luta pela cassação 
Cléber valoriza a participação popular e em sua fala são recorrentes expressōes como "luta", "comunidade", "injustiça". No contexto de sua narrativa, tais expressóes remetem a um projeto político, cuja igualizaçáo das relaçóes sociais esteja na base. Por outro lado, Cléber recentemente fechou um acordo com o prefeito, pelo qual, em troca de apoio da associaçáo, o prefeito se comprometeu a "trabalhar pro bairro".

A análise da entrevista de Cléber revela suas referências e sua prática política. Ele é um remanescente da luta contra a privatizaçáo dá água ${ }^{23}$ e se refere a esta luta como a um marco político para Sarandi, resultado da uniáo do povo:

[...] Eu acho que foi uma conquista do povo de Sarandi aquela luta lá, cara. Porque, igual eu falei pra você, o povo unido, cara, o povo unido ele tem força [...] Então foi, foi um basta, uns falam que eu foi dum jeito, mas eu falo assim: a comunidade unida, ela jamais será vencida, pode vir quem for. Então naquele ano eu acho que foi um marco pra cidade. E até hoje tá a água aí, não precisou de privatizar [...] (Cléber, entrevista, 2012).

Essa concepçáo participativa náo fica guardada no passado, mas ainda é referência atual para Cléber, que entende que uma associaçáo que conte com a participaçấo ativa dos moradores se fortalece e pode trazer "avanço" para o bairro:

Quanto mais membros você colocar dentro de uma associação, quanto mais associado tiver, a associação pega força. [...] A gente tem as pesquisas na mão, a gente tem associação aqui no, no Sarandi mesmo que ela tá caminhando sozinha, por quê? Ela conseguiu engajar os moradores dentro, se nóis conseguir a gente vai avançar bastante (Cléber, entrevista, 2012).

De acordo com Cléber, por meio da participaçáo popular, eles poderáo implementar o projeto "Bairro Bom de Viver", o qual vem sendo arquitetado pela associaçáo e tem por objetivo realizar uma mudança estrutural no bairro. A concretização deste projeto faria uma grande transformação no jardim, já que, segundo Cléber, existente há mais de quarenta anos, ainda não é asfaltado, náo possui posto de saúde, praças, tem muitos terrenos baldios com matagal, assaltos, tráfico de drogas e não tem políticas públicas para a juventude. Nesse sentido, o projeto intitulado "Bairro Bom de Viver" buscaria atacar em

do prefeito Milton Martini (Partido Progressista), também vitoriosa, ocorreu entre o fim de 2008 e início de 2009. Para outras informações, ver Priori (20/3).

23 Ver nota anterior. 
todas em frentes visando construir um bairro estruturado e com assistência às famílias e aos jovens em situação de vulnerabilidade social.

Recentemente Cléber celebrou um acordo com o prefeito conservador Carlos De Paula, numa clara estratégia de atrair a atençáo do poder público municipal para o bairro: "É, nós tivemos a oportunidade do ano passado a gente ter fechado um acordo com ele, pra ele trabalhar pro bairro mais, aí. É por isso que a gente tá conseguindo muita coisa" (Cléber, entrevista, 2012). Assim, ao mesmo tempo em que Cléber elabora um discurso crítico, denunciando as dificuldades em ter acesso ao poder municipal, do abandono que o bairro enfrenta historicamente, ele procura atrair os olhares do prefeito e de pelo menos alguns vereadores, porque "se você náo tá dentro da política municipal, você náo consegue discutir nada" (Cléber, entrevista, 2012).

Náo obstante a parceria firmada, Cléber náo se esquiva das críticas ao prefeito, o que deixa clara a consciência da sua escolha estratégica pela parceira com o prefeito:

O relacionamento com o prefeito é, olha, eu vou falar pro cê assim, é difícil, se fosse possível, hoje, hoje a gente tem, conseguiu é uma história aí com prefeito. Mas de cada, é, vamos supor assim, de cada doze meses que você vai lá, você consegue uma [...], uma conversa, a cada doze meses. É, nós tivemos a oportunidade do ano passado a gente ter fechado um acordo com ele, pra ele trabalhar pro bairro mais, aí. É por isso que a gente tá conseguindo muita coisa. Mas eu vejo cara, eu acho que a associação ela tem que ter relacionamento com o prefeito e o prefeito deveria e como obrigação como ele é, é um homem público, e ele é prefeito da cidade inteira: ele deveria não só ter compromisso com a associação, mas sim assumir as consequências que a associação precisa (Cléber, entrevista, 2012).

Apesar de reconhecer que o dever do prefeito é com o coletivo, Cléber entende que somente se mantiver esse acordo, mesmo com dificuldades de ter acesso ao prefeito, poderá avançar no atendimento das necessidades do bairro.

Mediante os fatos mencionados, é possível afirmar que os casos de Cléber e Joel ilustram posiçóes que mesclam elementos de um projeto político conservador e outro democrático-participativo, sendo comum o trânsito entre uma e outra concepçáo de mundo e a mobilizaçáo de diferentes estratégias de mediaçáo de suas demandas. Nesse sentido, estes sujeitos acabam por formular um padrão de atuaçấo capaz de selecionar estratégias distintas, no intuito de minimizar as necessidades do bairro. $\mathrm{O}$ caso de Joel narra a constituiçáo de 
uma conformação associativa que nasce de um grupo político, cujas relaçōes pessoais e as decisóes tomadas pelo alto são prática comum. Nesse sentido, Joel, ligado afetivamente a tais sujeitos, encara com naturalidade tal padráo de ação e o mobiliza quando necessário. Por outro lado, Joel reconhece a necessidade da formulaçáo de movimentos de protesto em casos que náo haja alternativa.

Cléber, por sua vez, teve boa experiência nas lutas populares de Sarandi, participando de atos públicos, organizaçóes e mobilizaçóes por melhorias nos bairros. Apesar de crítico dos elementos não universalistas da gestáo municipal, fez parceria com o prefeito, com o intento de conquistar mais "benfeitorias" para o bairro. Nesse sentido, a formulaçáo de espaços públicos e o conflito, próprio da política, são colocados em segundo plano, com o intuito de minorar os problemas do bairro.

\section{Considerações finais}

Iniciamos este artigo apresentando referências teóricas que ajudassem na análise das organizaçōes populares no município de Sarandi. Tais referências foram buscadas em autores como K. Marx, E. Thompson, Hannah Arendt, Eder Sader, E. Dagnino, M. K. Silva e G. Ottmann, os quais indicam possíveis caminhos a seguir e orientam as perguntas e as consideraçóes feitas acerca das configuraçóes assumidas por associaçóes de moradores de Sarandi.

A pesquisa realizada buscou amparo nos autores citados anteriormente porque visava uma abordagem que considerasse a influência dos condicionantes estruturais, mas que náo bloqueasse a análise da capacidade criativa do ser humano. Portanto, este artigo centrou a análise na ação dos sujeitos políticos em foco, mas sem deixar de considerar o contexto histórico-social ao qual estáo inseridos, bem como o peso da estrutura sobre eles. Tais referências criaram condiçóes para que pudéssemos compreender as principais características dos projetos políticos em disputa em Sarandi, as estratégias traçadas por seus atores e mesmo suas contradiçóes.

Assim, encontramos três padróes assumidos por associaçóes de moradores em Sarandi. Tais vertentes náo sáo compreendidas como blocos fechados, mas como processos em disputa. Analisamos um projeto político de padrão conflitivo, por herdar a tradiçáo de luta e contestaçáo dos movimentos sociais e por 
alargar o espaço da política. Abordamos ainda um grupo de associaçóes que se caracteriza pela mobilizaçáo de vínculos privados e busca de influências de políticos tradicionais para o alcance de suas demandas. Em meio a estes perfis, fomos obrigados a forjar um conceito capaz de expressar as singularidades de um terceiro grupo de associaçóes. Analisados sob a noçáo de seleçâo estratégica, este grupo se diferencia pela mobilizaçáo de elementos tanto conflitivos como conciliadores para conquista de suas reivindicaçóes de acordo com as possibilidades de êxito de uma ou outra estratégia.

Esta pesquisa, evidentemente, não pretende esgotar o tema, tampouco possui pretensáo generalizadora. De fato, novas frentes de pesquisa se abrem a partir das consideraçóes aqui traçadas. Entre o amplo trabalho ainda por ser feito, consideramos urgente olhar com mais cuidado para o que apresentamos como seleçáo estratégica, com o intento de pôr o conceito a prova em outras localidades. Quais as consequências dessa configuraçáo para a construçáo democrática? É possível encontrar configuraçóes semelhantes em outros contextos? Qual a relação desse fenômeno com a política contemporânea? Quais os impactos da seleçáo estratégica para a tradição dos movimentos sociais? Como os setores políticos conservadores lidam com a seleção estratégica? Quais os limites dessa trama? Questóes como estas e outras que possam vir a ser formuladas, em nossa avaliaçáo, abrem uma nova agenda de pesquisa.

\section{Referências}

ARENDT, H. A condição humana. 11. ed. Rio de Janeiro: Forense Universitária, 2010.

DAGNINO, E. Confluência perversa, deslocamento de sentido, crise discursiva. In: GRIMSON, A. (Ed.). La cultura em las crisis latino-americanas. Buenos Aires: Clacso, 2004. Disponível em: $<$ http://biblioteca.clacso.edu.ar/subida/clacso/gt/20100918091218/10dagnino.pdf.ori>. Acesso em: 1 mar. 2011.

Cultura, cidadania e democracia: a transformaçáo dos discursos e práticas na esquerda latino-americana. In: ALVARES, S. E.; DAGNINO, E.; ESCOBAR, A. Cultura e política nos movimentos sociais latino-americanos: novas leituras. Belo Horizonte: Ed. UFMG, 2000.

DAGNINO, E.; OLVERA, A. J.; PANFICHI, A. (Org.). A disputa pela construçáo democrática na América Latina. São Paulo: Paz e Terra; Campinas: UNICAMP, 2006.

FELTRAN, G. de S. Desvelar a política na periferia: história de movimentos sociais em Sáo Paulo. Sáo Paulo: Associaçáo Editorial Humanitas; FAPESP, 2005. 
GURZA LAVALLE, A. Espaço e vida públicos: reflexóes teóricas e sobre o pensamento brasileiro. 2001. Tese (Doutorado em Ciência Política)-Universidade de Sáo Paulo, Sáo Paulo, 2001.

MARX, K. O 18 brumário de Luís Bonaparte. In: O 18 brumário e cartas a Kugelmann. Traduçáo Leandro Konder e Renato Guimaráes. Rio de Janeiro: Paz e Terra, 1997.

OTTMANN, G. Cidadania mediada: processos de democratização da política municipal no Brasil. Novos Estudos, v. 74, mar. 2006. Disponível em: <http://www.scielo.br/pdf/nec/n74/29645.pdf>. Acesso em: 1 mar. 2011.

PRIORI, J. Conflito, seleçáo estratégica e conciliaçáo: política e democracia na ação de setores populares em Sarandi-PR. 2013. Dissertação (Mestrado em Ciências Sociais)-Programa de PósGraduação em Ciências Sociais, Universidade Estadual de Maringá, Maringá, 2013.

RODRIGUES, A. L. A pobreza mora ao lado: segregaçāo socioespacial na regiáo metropolitana de Maringá. 2004. Tese (Doutorado em Ciências Sociais)-Programa de Pós-Graduação em Ciências Sociais, Pontifícia Universidade Católica de Sáo Paulo, Sáo Paulo, 2004.

SADER, E. Quando novos personagens entraram em cena: experiências, falas e lutas dos trabalhadores da Grande São Paulo (1970-1980). 4. ed. Rio de Janeiro: Paz e Terra, 1988.

SILVA, M. K. Sociedade civil e construçáo democrática: do maniqueísmo essencialista à abordagem relacional. Sociologias, Porto Alegre, ano 8, jul./dez. 2006.

THOMPSON, E. P. A formaçáo da classe operária inglesa 1: a árvore da liberdade. 6. ed. Sáo Paulo: Paz e Terra, 2011.

A formação da classe operária inglesa, 2: a maldiçáo de Adão. 2. ed. São Paulo: Paz e Terra, 2012.

TONELLA, C. Cultura política, dimensóes do exercício da cidadania e participação na vida pública em cidades da região metropolitana de Maringá-PR. In: CONGRESSO LATINO-AMERICANO DE OPINIÁO PÚBLICA DA WAPOR, 4., 2011, Belo Horizonte. Disponível em: <http://www. waporbh.ufmg.br/papers/Celene_Tonella.pdf>. Acesso em: 28 fev. 2012.

WILLIAMS, R. Marxismo e literatura. Rio de Janeiro: Zahar, 1979.

Recebido em 01.09.2013

Aprovado em 27.06.2014 


\section{Collective action and social movements: in search of an analytical methodology}

\section{Abstract}

This article aims to present the results of a researchof residents' associations in the city of Sarandi, Paraná. The incorporation of a set of theoretical references that value human action without neglecting the influence of the structure allowed to analyze the political action of subject associations, recognizing their creative ability, but considering the historical and social influences, is at the local level or wider. Such research has led us to identify the formation of three patterns of activity in the group of neighborhood associations in Sarandi, namely democratic participatory, governing and what we call strategic selection, a concept coined by us from the analysis of the survey data.

Keywords: Human action. Political project. Democracy. 